\title{
The Lake El'gygytgyn Scientific Drilling Project - Conquering Arctic Challenges through Continental Drilling
}

\author{
by Martin Melles, Julie Brigham-Grette, Pavel Minyuk, Christian Koeberl, Andrei Andreev, \\ Timothy Cook, Grigory Fedorov, Catalina Gebhardt, Eeva Haltia-Hovi, \\ Maaret Kukkonen, Norbert Nowaczyk, Georg Schwamborn, \\ Volker Wennrich, and the El'gygytgyn Scientific Party
} doi:10.2204/iodp.sd.11.03.2011

\section{Abstract}

Between October 2008 and May 2009, the International Continental Scientific Drilling Program (ICDP) co-sponsored a campaign at Lake El'gygytgyn, located in a 3.6-Ma-old meteorite impact crater in northeastern Siberia. Drilling targets included three holes in the center of the 170-m-deep lake, utilizing the lake ice cover as a drilling platform, plus one hole close to the shore in the western lake catchment. At the lake's center. the entire 315-m-thick lake sediment succession was penetrated. The sediments lack any hiatuses (i.e., no evidence of basin glaciation or desiccation), and their composition reflects the regional climatic and environmental history with great sensitivity. Hence, the

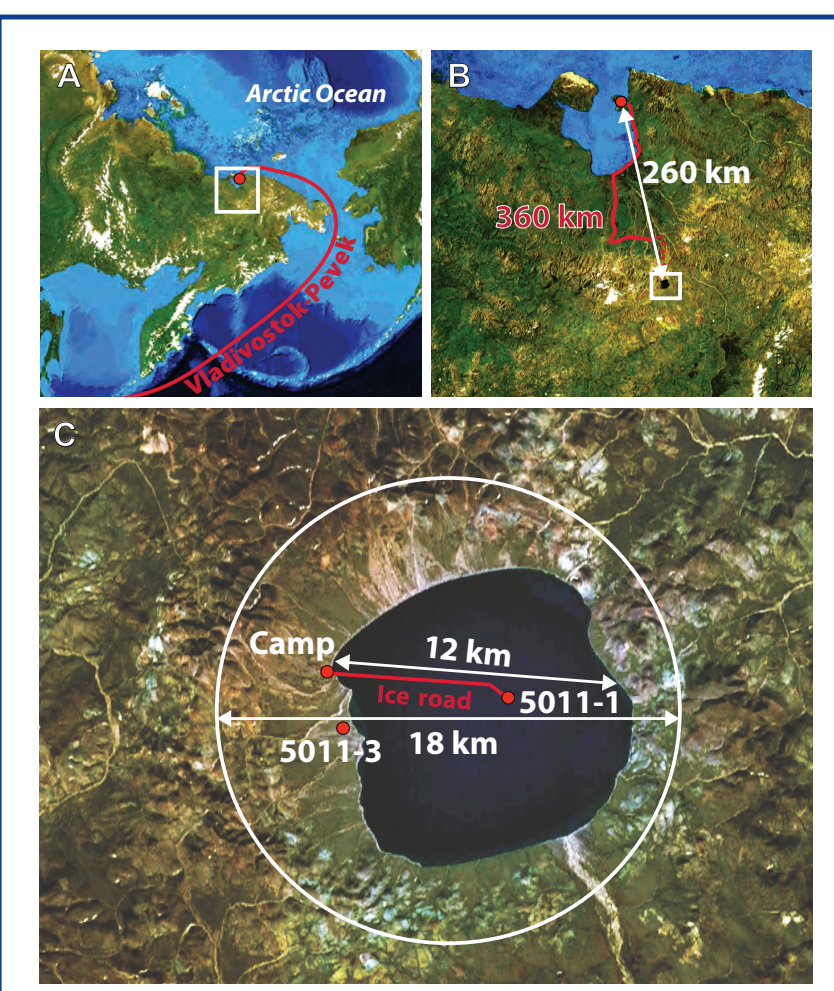

Figure 1. Location and setting of Lake El'gygytgyn. [A] The lake is located in central Chukotka, NE Russia, about $850 \mathrm{~km}$ west of the Bering Strait. The drill rig and all equipment arrived at the lake first by barge from Vladivostok along the route in red. [B] All logistics were based out of the town of Pevek, a gold mining center located on the coast of the East Siberian Sea. Helicopters were used to transport scientists, food and delicate equipment out to the drill site, whereas the 17 shipping containers with the drilling system were transported by truck. [C] Satellite image of Lake El'gygytgyn Crater showing dimensions, regional relief, the locations of ICDP Sites 5011-1 and 5011-3, and the location of crater rim (white circle). record provides the first comprehensive and widely timecontinuous insights into the evolution of the terrestrial Arctic since mid-Pliocene times. This is particularly true for the lowermost 40 meters and uppermost 150 meters of the sequence, which were drilled with almost $100 \%$ recovery and likely reflect the initial lake stage during the Pliocene and the last $\sim 2.9 \mathrm{Ma}$, respectively. Nearly 200 meters of underlying rock were also recovered; these cores consist of an almost complete section of the various types of impact breccias including broken and fractured volcanic basement rocks and associated melt clasts. The investigation of this core sequence promises new information concerning the El'gygytgyn impact event, including the composition and nature of the meteorite, the energy released, and the shock behavior of the volcanic basement rocks. Complementary information on the regional environmental history, including the permafrost history and lake-level fluctuations, is being developed from a 142-m-long drill core recovered from the permafrost deposits in the lake catchment. This core consists of gravelly and sandy alluvial fan deposits in ice-rich permafrost, presumably comprising a discontinuous record of both Quaternary and Pliocene deposits.

\section{Introduction}

Lake El'gygytgyn is located $100 \mathrm{~km}$ to the north of the Arctic Circle in remote Chukotka, northeastern Russia $\left(67^{\circ} 30^{\prime} \mathrm{N}, 172^{\circ} 05^{\prime} \mathrm{E}\right.$; Fig. 1). The lake lies within a meteorite impact crater measuring $18 \mathrm{~km}$ in diameter (Gurov et al., $1978,2007)$ that was created 3.6 million years ago in volcanic target rocks (Layer, 2000). Today, the lake is 170-m-deep and has a roughly circular shape with a diameter of $12 \mathrm{~km}$. Higher sediment supply from the western and northern reaches of the crater over time has caused the displacement of the lake toward the southeastern part of the basin. The sediments in the surrounding lake catchment are derived from slope processes and fluvial activity. Regionally these sediments are thought to contain permafrost to a depth of $500 \mathrm{~m}$ (Yershov, 1998). A seismic survey on the lake floor detected more than 300 meters of lacustrine sediments above an impact breccia and brecciated volcanic bedrock (Gebhardt et al., 2006), confirming the assumption that the basin had escaped continental-scale glaciations since the time of the impact (Glushkova, 2001).

Because of its unusual origin and high-latitude setting in western Beringia, scientific drilling at Lake El'gygytgyn 
offered unique opportunities across three geoscientific disciplines. These include (i) paleoclimate research, allowing the timecontinuous reconstruction of the climatic and environmental history of the terrestrial Arctic back into the mid-Pliocene for the first time; (ii) permafrost research, promising a better understanding of the history and present behavior of the Arctic's frozen surficial materials; and (iii) impact science, providing new insights into planetary cratering processes and the response of volcanic target rocks. This report summarizes aspects of the pre-site surveys which provided the impetus for drilling, highlights the challenging, sometimes gut-wrenching drilling logistics, and outlines some results and first interpretations from the limited on-site and ongoing off-site analyses of the lake sediments, impact rocks, and permafrost deposits.

\section{Pre-site Surveys}

A first international expedition was carried out on Lake El'gygytgyn early in spring 1998. Using the lake ice as a platform, six participants from Germany, Russia, and the U.S.A. conducted initial shallow coring in the deepest part of the lake. Succeeding expeditions in summer 2000 and spring and summer 2003 included eleven and sixteen participants, respectively (Melles et al., 2005). These projects provided a more comprehensive understanding of the modern setting and processes operating in the crater, the Late Quaternary climatic and environmental history of the region, and the structure of the impact crater and the thickness and architecture of its lacustrine sediment infill (Brigham-Grette et al., 2007, and references therein).

The climate at Lake El'gygytgyn is cold, dry, and windy. In 2002, the mean annual air temperature was $-10.3^{\circ} \mathrm{C}$, with extremes ranging from $-40^{\circ} \mathrm{C}$ in winter to $+26^{\circ} \mathrm{C}$ in summer (Nolan and BrighamGrette, 2007). The annual precipitation amounted to $\sim 200 \mathrm{~mm}$ water equivalent. Dominant wind directions were either from the north or from the south. The mean hourly wind speed was $5.6 \mathrm{~m} \mathrm{~s}^{-1}$, with strong winds above $13.4 \mathrm{~m} \mathrm{~s}^{-1}$ occurring every month but more frequently in winter. The modern vegetation in the catchment of Lake El'gygytgyn is herb-dominated tundra with rare local patches of low shrubs, particularly willow (Salix) and dwarf

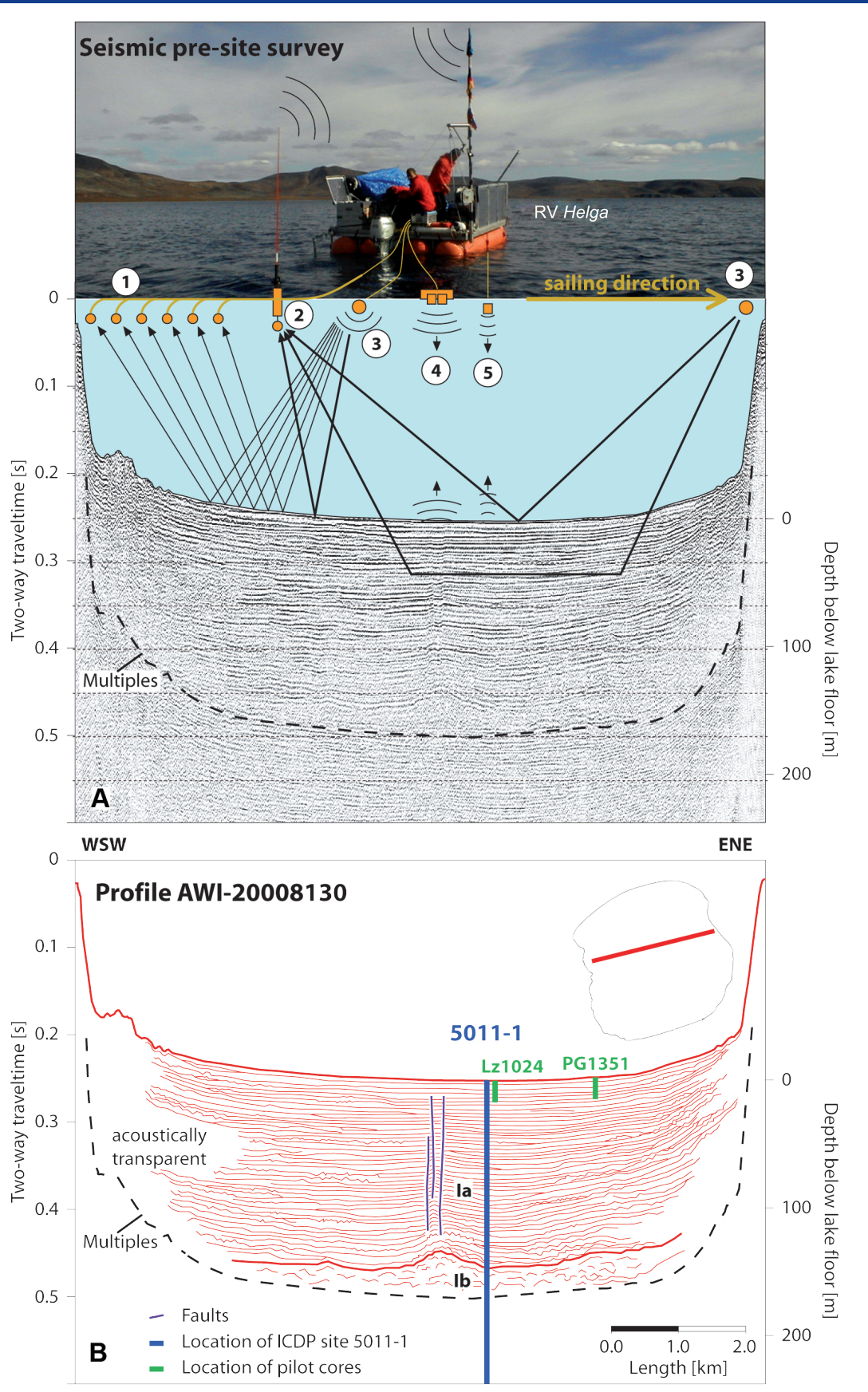

Figure 2. Seismic stratigraphy of Lake El'gygytgyn sediments. Multi-channel reflection profile AWI-20008130 is given as seismic image [A] and interpreted line drawing [B], with the trackline of the seismic profile shown in the inset. Seismic equipment used during the pre-site surveys in 2000 and 2003 is shown in the diagram: (1) streamer (multi-channel: 14 channels, $260 \mathrm{~m}$ total length; single-channel: 20 elements single hydrophone), (2) sonobuoy (stationary hydrophone; seismic refraction and wide angle data), (3) airgun (expedition 2000: Bolt 600B, 5 inch $^{3}$; expedition 2003: Mini-Gl gun, 26 inch $^{3}$ ), (4) sediment echosounder $(3.5 \mathrm{kHz}$, penetration of $\sim 40 \mathrm{~m}$ ), and (5) bathymetric echosounder (water depth measurements along track lines). Note that the upper part of the sediments (Unit la) is seismically well-layered and interfingered by acoustically transparent mass movement deposits mainly in the proximal parts, while the lower part (Unit Ib) is acoustically more massive and chaotic.

birch (Betula nana) (Lozhkin et al., 2007a). Ice formation on Lake El'gygytgyn usually starts in October (Nolan et al., 2003). The blanketing snow cover melts in May/June, whereas the lake ice, which reaches a maximum thickness of 1.5-2.0 m, starts disintegration with the formation of moats at the shore in June/July and culminates in open water by mid-July/August. Biogenic primary production in this ultra- 
oligotrophic lake is concentrated in the short ice-free period in summer, but considerable phytoplankton growth also takes place beneath the ice cover (Cremer and Wagner, 2003; Cremer et al., 2005). Lake El'gygytgyn today is a cold-monomictic system with slightly acidic $\mathrm{pH}$. The water column down to $170 \mathrm{~m}$ is stratified in winter but completely mixed in summer, though never exceeding $4^{\circ} \mathrm{C}$ (Nolan and Brigham-Grette, 2007). About fifty streams enter the lake at $492 \mathrm{~m}$ above sea level (a.s.1.) from the catchment that extends to the crater rim up to $935 \mathrm{~m}$ a.s.1.; however, fluvial sediment supply to the lake is very low, because the watershed of $293 \mathrm{~km}^{2}$ is less than three times the lake's surface area of $110 \mathrm{~km}^{2}$. In addition, much of the sediment today is captured and deposited at the mouth of the inflows in shallow lagoons that are dammed by gravel bars formed by wave and lake ice action. The restricted fluvial input together with the low primary production produces remarkably clear surface waters, giving a Secchi transparency depth of $19 \mathrm{~m}$ in summer.

The first 13- and 16-m-long sediment cores from central Lake El'gygytgyn yielded basal ages of $250 \mathrm{kyr}$ and $340 \mathrm{kyr}$ before present (BP), respectively, confirming that very low and relatively constant sedimentation rates are characteristic of both interglacial and glacial times (Forman et al., 2007; Juschus et al., 2007; Nowaczyk et al., 2007). The highly variable characteristics of the sediment underscore the sensitivity of this lacustrine system to regional climatic and environmental change (Asikainen et al., 2007; Brigham-Grette et al., 2007; Cherepanova et al., 2007; Lozhkin et al., 2007a, 2007b; Melles et al., 2007; Minyuk et al., 2007). Shallow cores were also taken of sub-recent mass movement deposits first identified in seismic profiles as originating from the steep (up to $30^{\circ}$ ) lake slopes (Niessen et al., 2007). This case study demonstrated that debris and density flows can be associated with significant erosion on the lake slopes, but these processes usually do not reach the lake center, where suspension clouds produced by these events in most cases accumulate as non-erosive turbidites (Juschus et al., 2009). Complementary information concerning Late Quaternary lake-level fluctuations, cryogenic weathering, and landscape development was obtained by ground-penetrating radar surveys and investigations of sediment stratigraphic sections exposed in the catchment of Lake El'gygytgyn (Schwamborn et al., 2006, 2008a, 2008b; Glushkova and Smirnov, 2007; Glushkova et al., 2009).

During summer seismic surveys conducted in 2000 and 2003, a 3.5-kHz echosounder with high spatial resolution (up to $40 \mathrm{~m}$ penetration) was combined with single-channel and multi-channel airgun seismic systems to provide the clearest information possible of the deeper lacustrine sediments and the structure of the impact crater underneath (Gebhardt et al., 2006; Niessen et al., 2007). Both systems were run simultaneously for efficiency from a small open platform resting on four inflatable pontoons (Fig. 2). Sonobuoy refraction data from the lake center formed the basis of a five-layer velocitydepth model. The results show that the El'gygytgyn Crater has an uplifted central ring structure with its top in about $330 \mathrm{~m}$ depth below lake floor (mblf); the structure was built by impact breccia and buried by alluvial deposits in the northwestern part of the basin. Above this structure, two lake sediment units were identified based on seismic characteristics. According to the air gun reflection data, the upper unit down to 170 mblf appeared to be well stratified, while the lower unit appeared to be more massive (Fig. 2). Draping of the uplift structure is visible and inferred in the lower part of the upper unit. Both units were shown to be intercalated with thick mass movement deposits largely confined to marginal areas. Because these units also lack seismic discontinuities suggestive of glacial overriding or lake desiccation, a nearly time-continuous sediment record following the impact event was expected from parts of the central lake.

\section{Drilling Operation}

Drilling in remote northeastern Russia was a massive logistical undertaking. In summer 2008, the majority of the technical equipment and field supplies were transported in fifteen shipping containers from Salt Lake City, U.S.A. to Pevek, Russia by way of Vladivostok and the Bering Strait (Fig. 1). Additional freight from Germany (two containers) joined the cargo in Vladivostok via the Trans-Siberian Railway. In Pevek, the combined cargo was loaded onto trucks driven with bulldozer assistance more than $350 \mathrm{~km}$

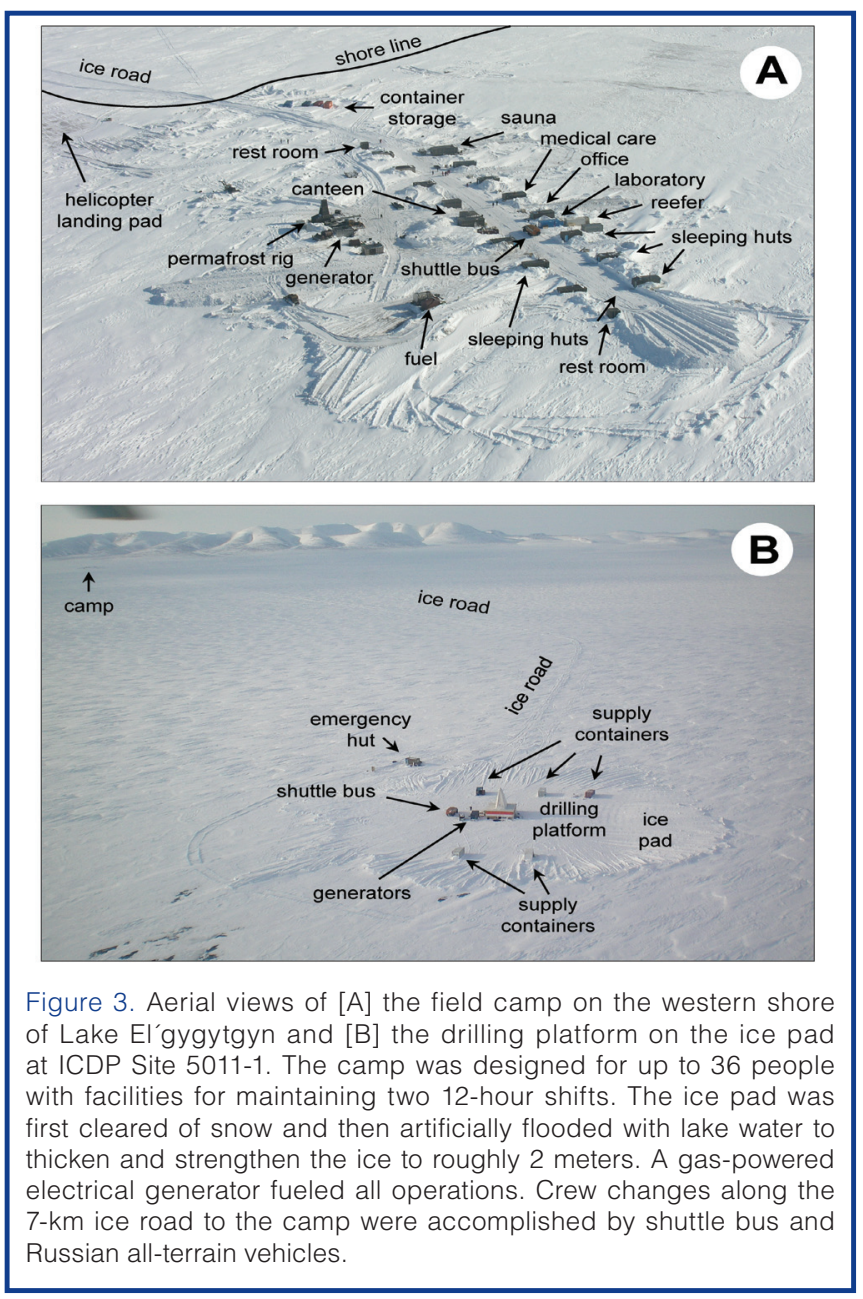




\section{Science Reports}

Table 1. Penetration, drilling and core recovery at ICDP Sites 5011-1 and 5011-3 in the El'gygytgyn Crater (all data given in field depth).

\begin{tabular}{|l|l|l|c|c|c|c|}
\hline Site & Hole & Type of Material & Penetrated (mblf) & Drilled (m) & Recovered (m) & Recovery (\%) \\
\hline $5011-1$ & 1A & lake sediment & 146.6 & 143.7 & 132.0 \\
\hline & 1B & lake sediment & 111.9 & 108.4 & 106.6 \\
\hline & 1C & total & 517.3 & 431.5 & 273.8 & 98 \\
\hline & & lake sediment & & 225.3 & 116.1 \\
\hline $5011-3$ & & impact rocks & & 207.5 & 157.4 \\
\hline
\end{tabular}

over winter roads and cross-country to Lake El'gygytgyn. There, the operation was supported by a temporary winter camp that was designed for up to thirty-six people and set up on the western lake shore (Fig. 3A). In the camp, a laboratory container for whole-core measurements of magnetic susceptibility stood next to a reefer in which the sediment cores were kept from freezing.

The project completed one borehole into permafrost deposits in the western lake catchment (ICDP Site 5011-3) and three holes at $170 \mathrm{~m}$ water depth in the center of the lake (Site 5011-1; Figs. 1, 4; Table 1). Permafrost drilling at Site 5011-3 was conducted from 23 November until 12 December 2008. Using a mining rig (SIF-650M) employed by a local drilling company (Chaun Mining Corp., Pevek), the crew reached a depth of $141.5 \mathrm{~m}$ with $91 \%$ recovery. After drilling, the borehole was permanently instrumented with a thermistor chain for future ground temperature monitoring as part of the "Global Terrestrial Network for Permafrost" (GTN-P) of the International Permafrost Association (IPA), thus contributing to our understanding of future permafrost behavior in light of contemporary rapid change.

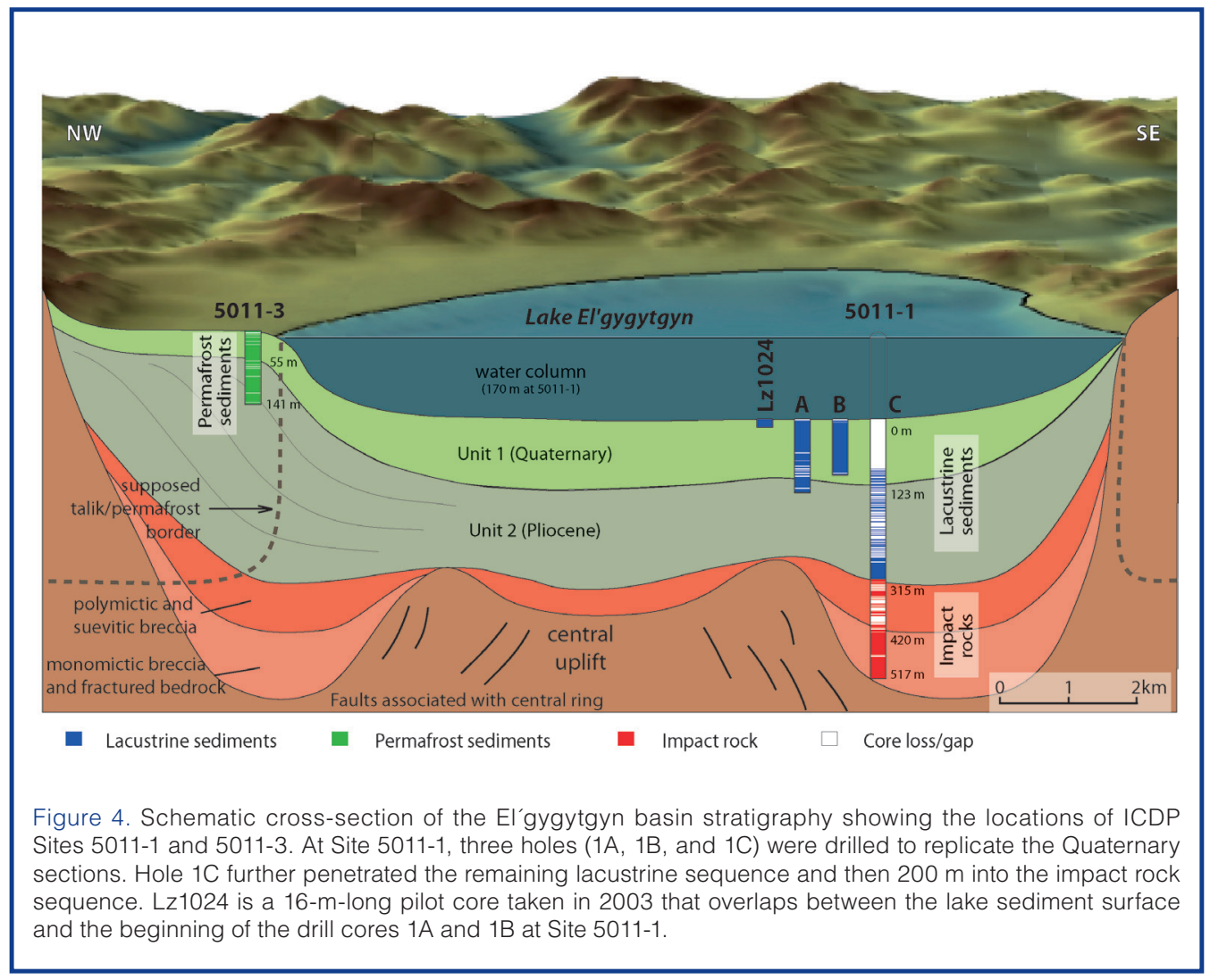

In January/February 2009 an ice road between the camp and Site 5011-1 on Lake El'gygytgyn was established (Figs. 1, 3B). Subsequently, an ice pad of $100 \mathrm{~m}$ diameter at the drill site was artificially thickened to $2.3 \mathrm{~m}$ to allow for lake drilling operations from the 100-ton drilling platform. The Russian GLAD 800 was developed for extreme cold and operated by the U.S. consortium DOSECC. It consisted of a modified Christensen CS-14 diamond coring rig positioned on a mobile platform that was weather-protected by insulated walls and a tent on top of the 20-m-high derrick. The system was permanently imported into Russia, where it is now available for scientific drilling projects at no cost until 2014.

Drilling at Site 5011-1 was conducted from 16 February to 26 April 2009. The drill plan included the use of casing anchored into the sediment to allow drilling to start at a field depth of 2.9 mblf. Holes $1 \mathrm{~A}$ and $1 \mathrm{~B}$ had to be abandoned after twist-offs at 147 mblf and 112 mblf, respectively. In Hole $1 \mathrm{~A}$ the Hydraulic Piston Corer (HPC) system was used down to 110 mblf, followed by the Extended Nose Corer (EXC) below. The recovery achieved with these tools was $92 \%$. Similarly, drilling with HPC down to 100 mblf and with EXC below provided $98 \%$ recovery in Hole 1B. Hole $1 \mathrm{C}$ was first drilled by HPC between 42 mblf and 51 mblf, in order to recover gaps still existing in the core composite from Holes $1 \mathrm{~A}$ and $1 \mathrm{~B}$, and was then continued from 100 mblf. Due to the loss of tools during the twist-offs, further drilling had to be performed with the Alien Bit Corer (ALN). The employment of this tool may at least partly explain a much lower recovery of the lake sediments in Hole 1C (total $52 \%$ ), although this could also be due to the higher concentration of gravel and sand in these deeper lake sediments. The recovery jumped up to almost $100 \%$ again at a depth of $265 \mathrm{~m}$, when the tool was changed to a Hard rock Bit Corer (HBC), which has a smaller 
diameter than the tools employed before. The boundary between lake sediments and impact rocks was encountered at 315 mblf. Further drilling into the impact breccia and brecciated bedrock down to 517 mblf by HBC took place with $76 \%$ recovery.

On-site processing of the cores recovered at Site 5011-1 involved magnetic susceptibility measurements with a multisensor core logger (MSCL, Geotek Ltd.) down to a depth of 380 mblf. Initial core descriptions were conducted based on macroscopic and microscopic investigations of the material contained in core catchers and cuttings (lake sediments) and on the cleaned core segments not cored with liners (impact rocks). Additionally, downhole logging was carried out in the upper $394 \mathrm{~m}$ of Hole $1 \mathrm{C}$ by the ICDP Operational Support Group (OSG), employing a variety of slim hole wireline logging sondes. Despite disturbance of the electrical and magnetic measurements in the upper part of the hole, due to the presence of metal after the twist-offs at Holes $1 \mathrm{~A}$ and $1 \mathrm{~B}$ and to some technical problems, these data provide important information on the in situ conditions in the hole (e.g., temperature, natural gamma ray, U, K, and Th contents) and permit depth correction of the individual core segments.

\section{Lake Sediments}

Based on the whole-core magnetic susceptibility measurements on the drill cores from ICDP Site 5011-1, the field team was able to confirm that the core composite from Holes $1 \mathrm{~A}$ to $1 \mathrm{C}$ provided nearly complete coverage of the uppermost $150 \mathrm{~m}$ of the sediment record in central Lake El'gygytgyn (Fig. 5), and that the gap between the top of the drill cores and the sediment surface was properly recovered by the upper part of a 16-m-long sediment core (Lz1024) taken during the 2003 site survey (Fig. 6). The construction of a final composite core record was completed during core processing and subsampling, which began in September 2009 at the University of Cologne, Germany, with the involvement of scientists from Russia and the U.S. The cores were first split lengthwise, and both core halves were macroscopically described and documented by high-resolution line scan images (MSCL CIS Logger, Geotek Ltd.). One core half was then used for measurements of color spectra and magnetic susceptibility in 1-mm increments (SCL2.3 Logger, GFZ Potsdam). This same core was then scanned using X-ray fluorescence (XRF) analyses of light and heavy elements and X-radiography in steps of $2.0 \mathrm{~mm}$ and $0.2 \mathrm{~mm}$,

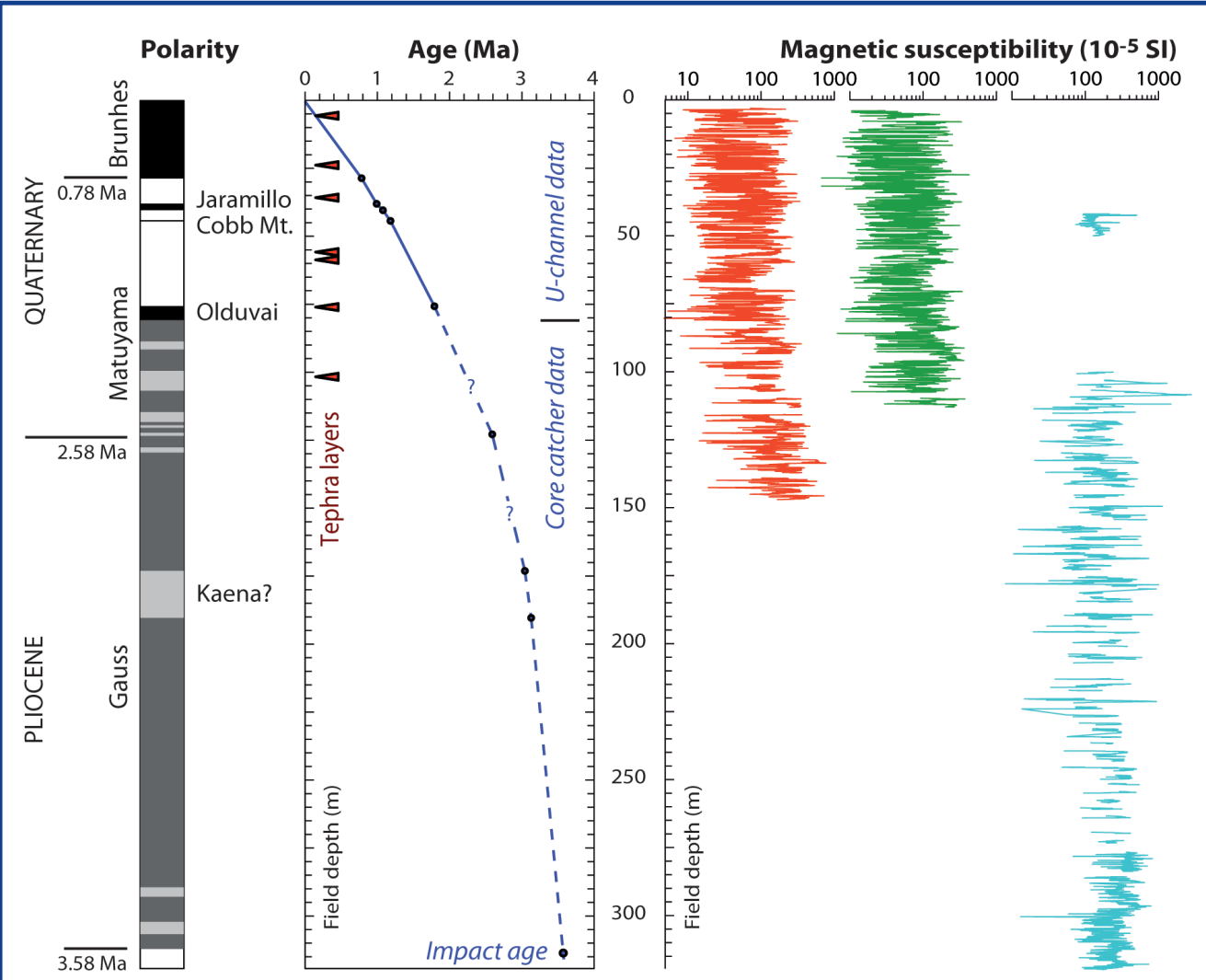

Figure 5. Preliminary paleomagnetic geochronology (left column) of the 315-m-thick lake sediment record from ICDP Site 5011-1 in the central part of Lake El'gygytgyn (for location see Figs. 1 and 4). Black and dark gray refer to normal polarity, white and light gray to reversed polarity, with gray shades representing uncertain interpretations. The age model presented still needs to be confirmed by ongoing paleomagnetic measurements on u-channels and dating of volcanic ash (tephra) layers. The data available so far indicate significantly decreasing sedimentation rates from the Pliocene into the Quaternary. The magnetic susceptibility (MS) data measured in the field (right columns) illustrate the high variability throughout the sediment succession, and that a core composite from Holes $1 \mathrm{~A}, 1 \mathrm{~B}$, and $1 \mathrm{C}$ provides an almost complete record down to about 150 mblf, representing the uppermost Pliocene and the entire Quaternary. respectively (ITRAX Core scanner, Cox Analytical Systems). Measurements of P-wave velocity and gamma-ray density (MSCL Logger, Geotek Ltd.) were then conducted in steps of $2 \mathrm{~mm}$ at the Alfred Wegener Institute in Bremerhaven, Germany, before the cores were continuously subsampled back in Cologne with u-channels for paleomagnetic and rock magnetic measurements. Subsequently, 2-cm-thick slices were continuously sampled from the core composite, excluding deposits from mass movement events, and split into eight aliquots of different sizes for additional biological and geochemical analyses. These aliquots, along with some irregular samples from replicate cores (e.g., for luminescence dating or tephra analyses), were subsequently sent to the science team members responsible for their analyses. In addition, thin sections were 
prepared from representative sections of the cores to facilitate microanalysis of the various lithologies identified during visual core descriptions. In 2011, the remaining untouched core halves will be shipped to the U.S. National Lacustrine Core Repository (LacCore) at the University of Minnesota for long-term archiving.

The current chronological information from the lake sediments relies predominantly on paleomagnetic measurements, which were continuously carried out on the u-channel samples at the GFZ, Potsdam, Germany. In the uppermost $78 \mathrm{~m}$ of the core composite, as yet based on uncorrected field depths, magnetozones with normal/reversed polarity can clearly be related to established polarity chrons and subchrons (Ogg and Smith, 2004), including the boundary between the Brunhes and Matuyama chrons (0.781 Ma; $\sim 28.5 \mathrm{mblf}$ ), the Jaramillo subchron (1.072-0.988 Ma; 40.5-38.0 mblf), the termination of the Cobb Mountain subchron (1.173 Ma; 44.2 mblf; its onset is masked by sediment disturbances at this level), and the termination of the Olduvai subchron (1.778 Ma; 75.5 mblf; Fig. 5). Below 78 mblf, paleomagnetic information is currently (December, 2010) restricted to initial measurements on semi-oriented discrete samples, which were taken roughly every $\sim 3 \mathrm{~m}$ from the core catcher samples in Holes $1 \mathrm{~A}, 1 \mathrm{~B}$, and $1 \mathrm{C}$. While these results need to be confirmed by the ongoing u-channel measurements, they suggest that the boundary between the Gauss and Matuyama chrons (2.581 Ma) is located at $123 \mathrm{mblf}$, where initial palynological data is consistent with an age close to the Pliocene/Pleistocene boundary. The sediment section with reversed polarity found in the upper part of the normal polarity Gauss chron is tentatively interpreted as the Kaena subchron (3.116-3.032 Ma; 190-173 mblf). Based on these results, and the assumption that Lake El'gygytgyn was formed shortly after the impact event at $3.58 \pm 0.04 \mathrm{Ma}$ (Layer, 2000), long-term sediment accumulation rates are found to be at a maximum in the early part of the record and to decrease in more recent deposits. Specifically, sedimentation rates decrease from $\sim 270 \mathrm{~mm} \mathrm{ka}^{-1}$ below the Kaena subchron, to $110 \mathrm{~mm} \mathrm{ka}^{-1}$ between the termination of the Kaena

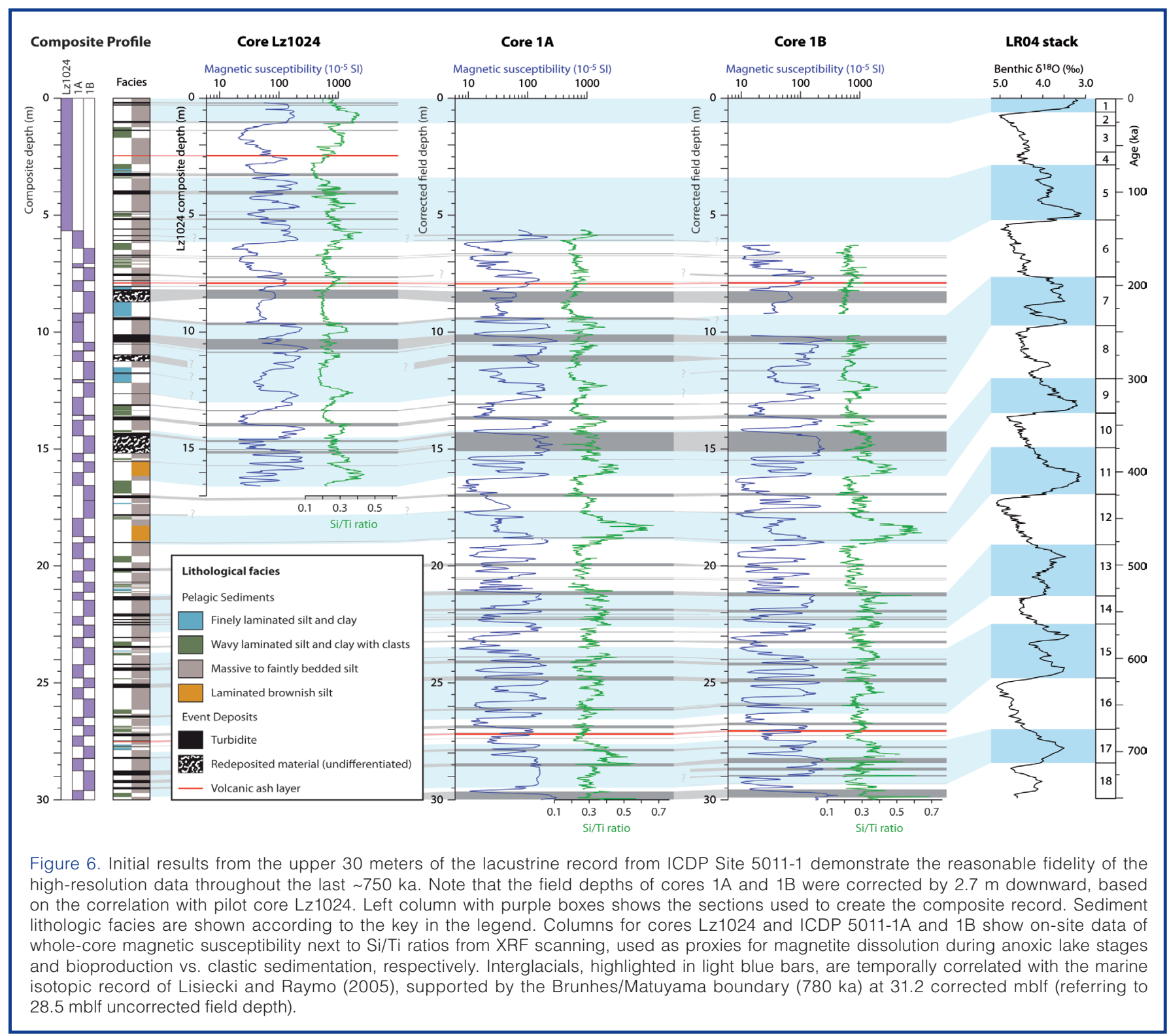


subchron and the Gauss/Matuyama boundary, to $~ 50 \mathrm{~mm} \mathrm{ka}^{-1}$ during the Quaternary. These preliminary chronological data are encouraging, because they confirm the feasibility of one of the major objectives of the El'gygytgyn Drilling Project, which is to investigate climatic developments during the Pliocene/Pleistocene transition and within the course of the Quaternary glacial/interglacial cycles. This can now be accomplished based on the core composite that was recovered from the uppermost $150 \mathrm{~m}$ of the lake sediment record.

Additional age control is expected to come from luminescence age estimates in the upper $\sim 30 \mathrm{~m}$ and from the numerical ages of seven tephra layers identified so far in the sediment record (Fig. 5); both are still in progress. The paleomagnetic, luminescence, and tephra ages will provide chronological tie points for a more detailed age model that will be derived from the correlation of high-resolution proxy measurements with regional insolation variations. This approach was successfully employed by Nowaczyk et al. (2007) on a 13-m-long core from a different location in central Lake El'gygytgyn. Preliminary results from the uppermost $30 \mathrm{~m}$ of the core composite at Site 5011-1 (Fig. 6) demonstrate that this approach should also function in the deeper sediments of Lake El'gygytgyn.

The lacustrine sediment succession at Site 5011-1 is remarkably heterogeneous. Changes in lithology occur every few centimeters to decimeters throughout the entire record (Fig. 6). Based primarily on visual characteristics, qualitative grain-size information, and sedimentary struc- tures observed in the split core halves and radiographs, the sediments are currently subdivided into four distinct facies reflecting continuous, pelagic deposition. Facies 1 is characterized by dark gray to black, finely laminated $(<5 \mathrm{~mm})$ silt and clay (Fig. 7A). Laminations are defined by alternating grain-size variations and are clearly observed as density variations in radiographs. Facies 2 is comprised of wavy laminations ( $<5 \mathrm{~mm}$ thick) of alternating silt and clay layers with an abundance of elongate sediment clasts made up of silt-sized particles (Fig. 7B). These clasts are typically several millimeters thick and have long axes up to $\sim 1 \mathrm{~cm}$ lying parallel to the bedding plane. The most abundant unit is classified as Facies 3 and is characterized by massive to faintly banded silt of various colors (Fig. 7C). Banding typically occurs as color variations $2-5 \mathrm{~cm}$ thick observed in split core halves, with only slight density variations observed in radiographs. Facies 4 consists of red or brownish silt-sized sediment with distinct fine laminations $(<5 \mathrm{~mm}$; Fig. 7D). In contrast to other laminated sections of the core, these laminae are not associated with any obvious grain-size variations and less pronounced density variations in the radiographs, possibly reflecting a biological or chemical origin.

Facies 1 through 3 are also present in a 13-m-long pilot core (PG1351) from which additional geochemical data are available and were related to different climate modes by Melles et al. (2007). According to that study, Lake El'gygytgyn had a perennial ice cover during glacial times and some stadials of the Late Quaternary. On one hand, this restricted light penetration and thus biogenic production in the surface waters, as reflected by low biogenic silica deposition (low Si/Ti ratios, Fig. 6). On the other hand, the perennial ice cover also hampered mixing of the water column, leading to anoxic $\mathrm{H}_{2} \mathrm{~S}$-bearing bottom waters and no bioturbation. Anoxic bottom waters dur-ing glacial/stadial times also lead to magnetite dissolution, reflected in low values of magnetic susceptibility (Nowaczyk et al., 2007). The glacial/stadial sediments in part consist of finely laminated silt and clay of Facies 1 (Fig. 7A). This facies is thought to reflect cold and relatively moist climates, when blanketing snow on the ice cover led to a reduction in biogenic primary production. In contrast, wavy laminated clast-containing sediments of Facies 2 (Fig. 7B) are pre-
Figure 7. Examples of X-radiographs and line scan pictures from sedimentary facies occurring in the lake sediment record from ICDP Site 5011-1. The sediments shown in [A] and [B] are characteristic for glacials/stadials, which differ in aridity, whereas the sediments shown in [C] and [D] are characteristic for interglacials/interstadials of different intensity. In addition, typical examples of a turbidite and a volcanic ash layer are shown in $[E]$ and $[F]$, respectively. 
sumed to reflect drier glacial intervals, when the absence of snow cover on the perennial ice allowed for a higher primary production. The clasts associated with Facies 2 may reflect enhanced deposition of aeolian material on the ice surface (forming cryoconites) followed by the agglomeration of these particles during their transport through the ice along vertical conduits. However, the precise origin and composition of these clasts are still being investigated.

Interglacial/interstadial sedimentation in Lake El'gygytgyn is to a degree reflected by the massive to faintly banded olive-gray to brownish sediments of Facies 3 (Fig. 7C). This facies reflects a semi-permanent ice cover that allows for a higher primary production, as evident in high $\mathrm{Si} / \mathrm{Ti}$ ratios (Fig. 6). A complete mixing of the water column at the end of ice breakup leads to oxygenation of the bottom waters, as indicated by the preservation of high magnetic susceptibilities. The predominantly massive appearance of the deposits is likely due to some homogenization by bioturbation. In contrast, fine laminations in Facies 4 (Fig. 7D) are indicative of a lack or strong limitation of bioturbation. These sediments also include dark organic-rich layers and are associated with distinct maxima in $\mathrm{Si} / \mathrm{Ti}$ ratios (Fig. 6). These characteristics are best attributed to deposition during an extraordinarily warm climate, with a prolonged ice-free period and enhanced nutrient supply from the catchment leading to exceptionally high rates of primary production and the exclusion of bioturbation due to depletion in oxygen content caused by enhanced decomposition of organic matter. Facies 4 last occurred at Lake El'gygytgyn during Marine Isotope Stages (MIS) 11 and 9.3 (Fig. 6). The details of this interpretation will require further study.

Pelagic sedimentation in Lake El'gygytgyn is irregularly interrupted by short-term sedimentary events (Fig. 6). These include gravitational mass movements and volcanic ash fallouts (Fig. 7E), which have formed up to 7.4-cm-thick tephra layers in the sediment record of Site 5011-1. Mass movement events are predominantly observed as turbidites, characterized by sharp basal contacts followed by a fining upwards sequence of sand to clay (Fig. 7F). Juschus et al. (2009) described the origin of the turbidites as resulting from sediment settling from suspension clouds produced by debris and density flows that originate on the lake slopes and occasionally penetrate into the center of the lake. Altogether, fifty-three graded beds have been identified in the upper $30 \mathrm{~m}$ of the Site 5011-1 record, and most are a few centimeters thick. Only three intervals with debrites, densites (Gani, 2004), or other re-deposited material related to mass movement events occur in this part of the core. Significant erosion by these mass movement events of the pelagic sediment record is not evident according to the age model for this part of the record, which is based on the correlation of sediment facies and proxy measurements with the global MIS stack (Fig. 6), constrained by the Brunhes/Matuyama boundary just below (Fig. 5).
The first information concerning the Pliocene history recorded in Lake El'gygytgyn relies on multi-proxy analyses of small samples taken from the core catchers (every $\sim 3 \mathrm{~m}$ ) and core cuttings (every meter). Based on these very preliminary data, we observe that the concentration of biogenic silica (BSi), total organic carbon (TOC), and total nitrogen (TN) is significantly lower in the Pliocene than in the Quaternary. Presumably, this is due to a much higher clastic input associated with significantly higher sedimentation rates during the Pliocene (Fig. 5). The Pliocene pollen assemblages are so far dominated mostly by tree pollen. Repeated changes in the plant assemblages through time reflect variations in forests of pine (Pinus), larch (Larix), spruce (Picea), fir (Abies), alder (Alnus), and hemlock (Tsuga). The tree pollen significantly decreases during the presumed Kaena subchron (3.116-3.032 Ma), concomitant with an increase in the relative abundance of wormwood (Artemisia) pollen-spores of rock spike-moss (Selaginella rupestris)_and coprophilous fungi. This pollen composition suggests treeless glacial environments - over some intervals - which can be described as tundra-steppe. The transition from the Pliocene to the Pleistocene still needs to be studied in detail, but it is broadly marked in the widely spaced samples studied so far by a distinct change from predominantly coniferous assemblages to pollen spectra dominated by dwarf birch, shrub alder, and herbs at 123 mblf.

\section{Impact Rocks}

The El'gygytgyn Crater represents the only currently known impact structure on Earth formed in siliceous volcanic rocks including tuffs. The impact melt rocks and target rocks provide an excellent opportunity to study shock metamorphism of volcanic rocks. The shock-induced changes observed in porphyritic volcanic rocks from El'gygytgyn can be applied to a general classification of shock metamorphism of siliceous volcanic rocks. That El'gygytgyn is an impact crater was confirmed in the late 1970 s by Gurov and co-workers (Gurov et al., 1978, 2007; Gurov and Koeberl, 2004), who found shocked minerals and impact glasses in samples at the crater. However, the impact rocks on the surface have been almost totally removed by erosion, and so the El'gygytgyn Drilling Project provides the unique opportunity to study the crater-fill impactites in situ and determine their relations and succession. The investigations are expected to provide information on the shock behavior of the volcanic target rocks, the nature and composition of the asteroid that formed the crater, and the amount of energy that was involved in the impact event. This will also allow us to constrain the effects this impact event had on the regional and circumarctic environment.

The impact portion of the drill core from ICDP Site 5011-1, spanning the interval $\sim 315-517$ mblf, was handled differently from the lake sediment portion to the extent that no special storage and temperature requirements were necessary for sample export from Pevek to our laboratories. The cores 
were initially shipped to the Natural History Museum in Berlin, where detailed basic core characterization was done (including complete photographic documentation) during the time period November 2009 to May 2010. In May 2010 an international sampling party was held in Berlin, and samples were allocated to about half a dozen research groups around the world.

The upper part of the impact core directly underneath the lake sediments consists of a unit of so-called suevitic breccia, with a thickness of $\sim 100 \mathrm{~m}$. A suevite is a glass-bearing polymict impact breccia, which contains fragments of a variety of rocks that represent different layers in the target rocks, cemented in a fine-grained matrix (Fig. 8). The glasses, on the other hand, were formed by the melting of the target rocks at very high temperatures. Such breccias are uniquely characteristic of impact craters on Earth and not found in any other geological setting. The green color of the suevite is due to alteration and the abundance of sheet minerals
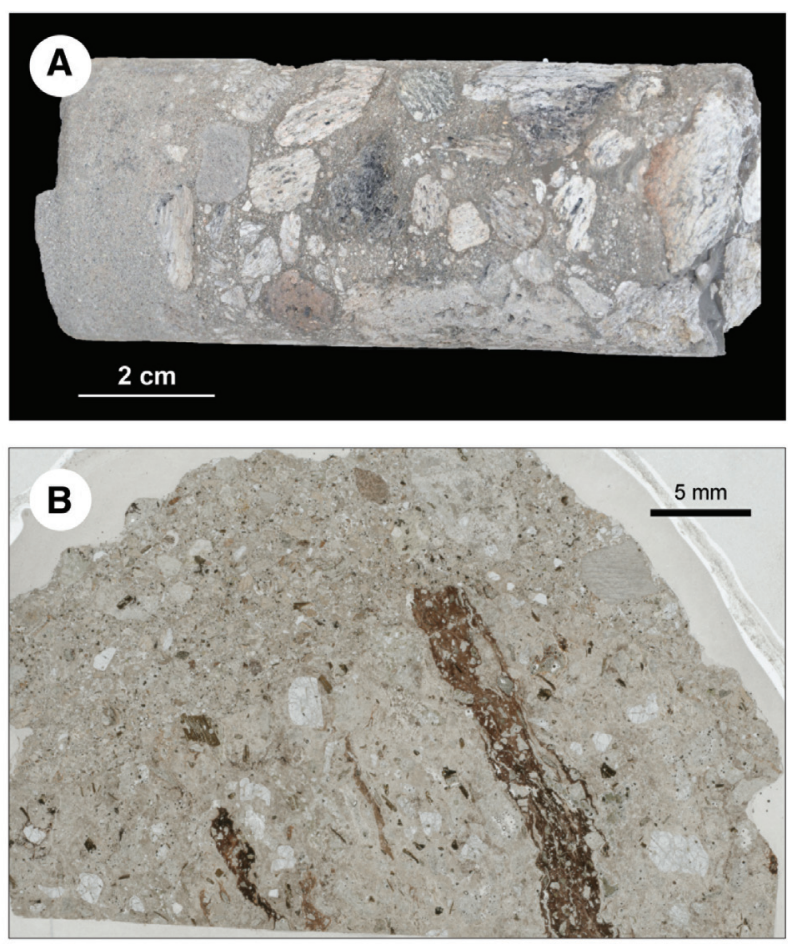

Figure 8. Typical suevitic impact breccia from the El'gygytgyn impact crater. [A] Core segment retrieved from a field depth of about 320 mblf at ICDP Site 5011-1. The rock fragments that occur in this breccia are a mixture of lithologies from the target that represent a pre-impact stratigraphic range of many hundred meters. [B] Thin-section of impact core sample 5011-107Q-4 from 343.8 mblf field depth, showing the so-called "red" suevite, which contains abundant large melt clasts, elongated and parallel to each other, comprising a general fluidal texture. The suevite is an impact breccia containing clastic components and melt clasts, and has a general light brownish color due to alteration into clay minerals. The largest melt clasts show internal fluidal texture. The groundmass of the melt clasts is glassy and brown. Clasts included are composed of fractured quartz, altered feldspar, and a minor amount of partially altered twinned amphibole. Lithic clasts include mainly fragmented quartz, fragmented and altered feldspars, finely twinned calcite, and fragments of volcanic rocks, which might be part of the target. The matrix of the suevite is microcrystalline, mainly composed of clay minerals that show a "fluidal" texture around the clasts. in the matrix; it contains abundant black melt clasts. The suevite shows a strong anisotropic fabric with fluidal texture. Fractures crosscutting the suevite are common, as are green clay and/or white-reddish carbonate veins. The suevites continue through a highly fractured transition zone with breccia intercalated to suevite and pass into a unit of shocked and locally brecciated volcanic target rocks (which may also contain suevitic breccias), which was uplifted during the impact event. During the formation of such central peaks, which are typical for impact craters of this size (also called "complex craters"), deeper layers of target rock rebound towards the surface and then solidify; thus, a mountain several kilometers in diameter is uplifted over $1000 \mathrm{~m}$ vertically in less than a minute. This is truly a spectacular geological process.

\section{Permafrost Deposits}

The single deep core obtained at ICDP Site 5011-3, from the western catchment of Lake El'gygytgyn, was entirely frozen when recovered. This confirmed modeling results, which suggested that the unfrozen talik alongside the lake descends with more or less a vertical boundary until the permafrost base is reached at a depth of a few hundred meters (Fig. 4). On site, the permafrost cores were initially described and photographically documented. They were kept frozen in the field and during transport to the ice laboratory at the Alfred Wegener Institute in Bremerhaven, Germany. There, the cores were cleaned, the documentation was completed, and subsamples were taken from the sediment and ice for ongoing laboratory analyses.

The permafrost core contains ground ice throughout and largely consists of sandy gravels with volcanic clasts embedded in a sandy matrix. In the uppermost $75 \mathrm{~m}$ processed so far, pollen has only been found in the uppermost $10 \mathrm{~m}$ and within a few thin intervals below (Fig. 9). Comparison of the pollen assemblages in these cores with those in nearby permafrost and lake sediment cores retrieved during the site surveys (Lozhkin et al., 2007a, 2007b; Glushkova et al., 2009; Shilo et al., 2008; Matrosova, 2009) remains somewhat speculative, because the reworking of slope materials from the alluvial fans still needs to be assessed. However, the pollen assemblages suggest that the upper $9 \mathrm{~m}$ at Site 5011-3 represent a discontinuous record back to the Allerød period, with the Holocene being restricted to the upper $1.8 \mathrm{~m}$ and the Younger Dryas represented by the interval $1.8-2.5 \mathrm{~m}$, and that the sediments at $\sim 20 \mathrm{~m}$ depth were formed during MIS 5.5 or 7 . While the pollen assemblages at $\sim 36 \mathrm{~m}$ and $\sim 51 \mathrm{~m}$ also indicate Pleistocene ages, those at about $62-65 \mathrm{~m}$ depth strongly indicate a Pliocene age for lower portions of the core, based on high pollen counts of pine (Pinus subgenus Haploxylon) as well as some of larch (Larix), fir (Abies), spruce (Picea), and hemlock (Tsuga; Fradkina, 1983). Hence, the Pliocene/Pleistocene boundary in core 5011-3 probably has to be placed somewhere between $51 \mathrm{~m}$ and $62 \mathrm{~m}$ depth, but additional study is required to test this conjecture. 
Organic matter occurs in significant amounts $(>1 \%)$ only in the Holocene sediments. The inferred climate oscillations for the transition from the Allerød via the Younger Dryas into the Holocene are also suggested in the water isotope record of the ground ice (Fig. 9). There, $\delta^{18} \mathrm{O}$ minima and maxima support the inferred vegetation history indicated by the pollen record. Below the Allerød, the $\delta^{18} \mathrm{O}$ values of the ground ice show less variation and tend toward more negative values, but not as negative as one would expect for full glacial values, like those seen in other regions of relict permafrost. The values observed here are currently interpreted to be due to a change in ice sources. While the ground ice in the Allerød and younger sediments likely originates from meteoric precipitation, the ice below could have been formed by freezing of lake sediment pore waters following a basinward migration of the talik boundary with lake lowering at some point in the past. Hence, it seems likely that the ground ice in these sediments is much younger than the enclosing sediments. A marginal lake environment prior to the Allerød is also indicated by the occasional occurrence of distinctly rounded pebbles, suggesting shore-line processes, and well-sorted sandy layers, possibly deposited on the upper lake slope. If this preliminary interpretation is confirmed by ongoing core analyses and modeling of the freezing front migrations, then the permafrost core 5011-3 may contribute to the reconstruction of the lake-level changes in the El'gygytgyn Crater since Pliocene times.

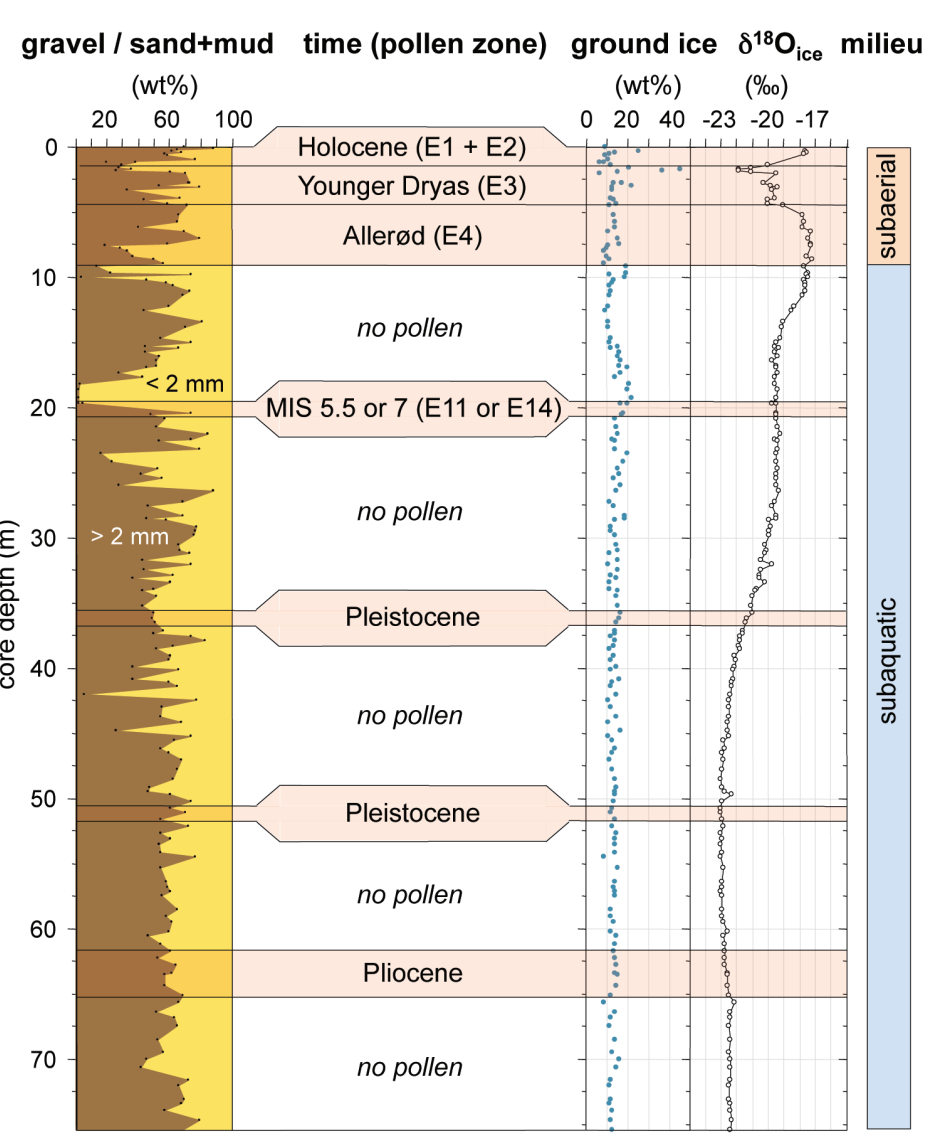

Figure 9. Initial results from the upper $75 \mathrm{~m}$ of the 141.5 -m-long core drilled at ICDP Site 5011-3 into permafrost on the western margin of the lake basin (for location see Figs. 1 and 4). The core consists of ice-rich, coarse-grained sediments, which indicate both subaerial but mainly subaquatic, near-shore deposition, and likely has numerous unconformities. The crude chronology so far existing for this sequence is based on similarities in pollen assemblages with known records. In the lower part of the core, pollen are rarely preserved; however, the assemblages between about $62 \mathrm{~m}$ and $65 \mathrm{~m}$ depth strongly suggest a Pliocene age of the respective sediments.

\section{Acknowledgements}

Marianna Voevodskaya (RAS/CRDF) provided a smooth transition for the field parties through Moscow. In Pevek, Dmitry Koselov from Chukotrosgidromet arranged all of the necessary paperwork required by local authorities. He also managed all of the in-town shuttle services and contacts with the airport. On-site, Nikolai Vasilenko and his colleagues from the Chaun Mining Corporation provided a friendly, cooperative atmosphere for daily operations in the base camp and during drilling crew shifts. Contracts for the camp were organized by $\mathrm{CH} 2 \mathrm{MH}$ ill. We are particularly grateful to the personnel in the Pevek office of the Kinross Gold Corporation for their assistance. Ice pad preparation and safety monitoring were carried out by EBA Engineering Consultants Ltd., Canada. The Russian GLAD 800 drilling system was developed and operated by DOSECC Inc., the downhole logging was performed by the ICDP-OSG, and LacCore at the University of Minnesota handled core curation.

Funding for this research was provided by the International Continental Scientific Drilling Program (ICDP), the U.S.
National Science Foundation (NSF), the German Federal Ministry of Education and Research (BMBF), Alfred Wegener Institute (AWI) and GeoForschungsZentrum Potsdam (GFZ), the Russian Academy of Sciences Far East Branch (RAS FEB), the Russian Foundation for Basic Research (RFBR), and the Austrian Federal Ministry of Science and Research (BMWF).

\section{The El'gygytgyn Scientific Party}

P. Anderson, A. Andreev, I. Bindeman, D. Bolshiyanov, V. Borkhodoev, K. Brady, J. Brigham-Grette (Principal Investigator), L. Brown, S. Burns, B. Chabligin, M. Cherepanova, T. Cook, R. Deconto, G. Fedorov, S. Forman, A. Francke, D. Froese, C. Gebhardt, O. Glushkova, V. Goette, J. Griess, A. Hilgers, A. Holland, E. Haltia-Hovi, H.-W. Hubberten, O. Juschus, J. Karls, C. Koeberl (Principal Investigator), S. Koenig, C. Kopsch, M. Kukkonen, P. Layer, A. Lozhkin, K. Mangelsdorf, T. Martin, T. Matrosova, H. Meyer, C. Meyer-Jacob, M. Melles (Principal Investigator), P. Minyuk (Principal Investigator), K. Murdock, F. Niessen, M. Nolan, A. Noren, N. Nowaczyk, N. Ostanin, S. Petsch, L. 
Pittarello, V. Ponomareva, M. Portnyagin, F. Preusser, V. Pushkar, U. Raschke, J. Reed, P. Rosén, G. Schwamborn, V.S. Sakhno, T. Sapelko, N. Savva, L. Schirrmeister, V. J. Snyder, V.N. Smirnov, C. Van den Bogaard, H. Vogel, B. Wagner, D. Wagner, V. Wennrich, K. Wilkie.

\section{References}

Asikainen, C.A., Francus, P., and Brigham-Grette, J., 2007. Sedimentology, clay mineralogy and grain-size as indicators of $65 \mathrm{ka}$ of climate change from El'gygytgyn Crater Lake, northeastern Siberia. J. Paleolimnol., 37:105-122, doi:10.1007/s10933-006-9026-5.

Brigham-Grette, J., Melles, M., Minyuk, P., and Scientific Party, 2007. Overview and significance of a $250 \mathrm{ka}$ paleoclimate record from El'gygytgyn Crater Lake, NE Russia. J. Paleolimnol., 37:1-16, doi:10.1007/s10933-006-9017-6.

Cherepanova, M.V., Snyder, J.A., and Brigham-Grette, J., 2007. Diatom stratigraphy of the last $250 \mathrm{ka}$ at Lake El'gygytgyn, northeast Siberia. J. Paleolimnol., 37:155-162, doi:10.1007/ s10933-006-9019-4.

Cremer, H., and Wagner, B., 2003. The diatom flora in the ultra-oligotrophic Lake El'gygytgyn, Chukotka. Polar Biol., 26:105114, doi:10.1007/s00300-002-0445-0.

Cremer, H., Wagner, B., Juschus, O., and Melles, M., 2005. A microscopical study of diatom phytoplankton in deep crater Lake El'gygytgyn, northeast Siberia. Algol. Studies, 116:147-168, doi:0342-1120/04/0157-147.

Forman, S.L., Pierson, J., Gomez, J., Brigham-Grette, J., Nowaczyk, N.R., and Melles, M., 2007. Luminescence geochronology for sediments from Lake El'gygytgyn, northwest Siberia, Russia: constraining the timing of paleoenvironmental events for the past 200 ka. J. Paleolimnol, 37:77-88, doi:10.1007/s10933-006-9024-7.

Fradkina, A.F., 1983. Neogene Palynofloras of Northeast Asia. Moscow (Nauka), [in Russian].

Gani, M.R., 2004. From turbid to lucid: a straightforward approach to sediment gravity flows and their deposits. The Sedimentary Record, 2:4-8.

Gebhardt, A.C., Niessen, F., and Kopsch, C., 2006. Central ring structure identified in one of the world's best-preserved impact craters. Geology, 34:145-148, doi:10.1130/G22278.1.

Glushkova, O.Y., 2001. Geomorphological correlation of Late Pleistocene glacial complexes of Western and Eastern Beringia. Quat. Sci. Rev., 20:405-417, doi:10.1016/ S0277-3791(00)00108-6.

Glushkova, O.Y., and Smirnov, V.N., 2007. Pliocene and Holocene geomorphic evolution and paleogeography of the El'gygytgyn Lake region, NE Russia. J. Paleolimnol., 37:37-47, doi:10.1007/s10933-006-9021-x.

Glushkova, O.Y., Smirnov, V.N., Matrosova, T.V., Vazhenina, L.N., and Braun, T.A., 2009. Climatic-stratigraphic characteristics and radiocarbon dates from the terrace complex in the El'gygytgyn Lake basin. Vestnik FEB RAS, 2:31-43 [in Russian].

Gurov, E.P., and Koeberl, C., 2004. Shocked rocks and impact glasses from the El'gygytgyn impact structure (Russia). Meteorit.
Planet. Sci., 39:1495-1508, doi:10.1111/j.1945-5100.2004. tb00124.x.

Gurov, E.P., Koeberl, C., and Yamnichenko, A., 2007. El'gygytgyn impact crater, Russia: structure, tectonics, and morphology. Meteorit. Planet. Sci., 42:307-319, doi:10.1111/j.1945-5100. 2007.tb00235.x.

Gurov, E.P., Valter, A.A., Gurova, E.P., and Serebrennikov, A.I., 1978. Meteorite impact crater El'gygytgyn in Chukotka. Dokl. Akad. Nauk SSSR+, 240:1407-1410 [in Russian].

Juschus, O., Melles, M., Gebhardt, A.C., and Niessen, F., 2009. Late Quaternary mass movement events in Lake El'gygytgyn, north-eastern Siberia. Sedimentol., 56:2155-2174. doi:10.1111/j.1365-3091.2009.01074.x.

Juschus, O., Preusser, F., Melles, M., and Radtke, U., 2007. Applying SAR-IRSL methodology for dating fine-grained sediments from Lake El'gygytgyn, north-eastern Siberia. Quat. Geochron., 2:187-194, doi:10.1016/j.quageo.2006.05.006.

Layer, P., 2000. Argon-40/argon-39 age of the El'gygytgyn impact event, Chukotka, Russia. Meteorit. Planet. Sci., 35:591-599, doi:10.1111/j.1945-5100.2000.tb01439.x.

Lisiecki, L.E., and Raymo, M.E., 2005. A Pliocene-Pleistocene stack of 57 globally distributed benthic $\delta^{18} \mathrm{O}$ records. Paleoceanography, 20:PA1003, doi:10.1029/2004PA001071.

Lozhkin, A.V., Anderson, P.M., Matrosova, T.V., and Minyuk, P., 2007a. The pollen record from El'gygytgyn Lake: implications for vegetation and climate histories of northern Chukotka since the late middle Pleistocene. J. Paleolimnol., 37:135-153, doi:10.1007/s10933-006-9018-5.

Lozhkin, A.V., Anderson, P.M., Matrosova, T.V., Minyuk, P.S., Brigham-Grette, J., and Melles, M., 2007b. Continuous record of environmental changes in Chukotka during the last 350 thousand years. Russ. J. Pac. Geol., 1:550-555, doi:10.1134/S1819714007060048.

Matrosova, T.V., 2009. Vegetation and climate change in northern Chukotka during the last $350 \mathrm{ka}$ (based on lacustrine pollen records from Lake El'gygytgyn). Vestnik FEBRAS, 2:23-30 [in Russian].

Melles, M., Brigham-Grette, J., Glushkova, O.Y., Minyuk, P., Nowaczyk, N.R., and Hubberten, H.-W., 2007. Sedimentary geochemistry of a pilot core from El'gygytgyn Lakea sensitive record of climate variability in the East Siberian Arctic during the past three climate cycles. J. Paleolimnol., 37:89-104, doi:10.1007/s10933-006-9025-6.

Melles, M., Minyuk, P., Brigham-Grette, J., and Juschus, O., 2005. The Expedition El'gygytgyn Lake 2003 (Siberian Arctic). Ber. Polarforsch. Meeresforsch. 505:139 pp.

Minyuk, P., Brigham-Grette, J., Melles, M., Borkhodoev, V.Y., and Glushkova, O.Y., 2007. Inorganic geochemistry of El'gygytgyn Lake sediments, northeastern Russia, as an indicator of paleoclimatic change for the last $250 \mathrm{kyr} . J$. Paleolimnol., 37:123-133. doi:10.1007/s10933-006-9027-4.

Niessen, F., Gebhardt, A.C., Kopsch, C., and Wagner, B., 2007. Seismic investigation of the El'gygytgyn impact crater lake (Central Chukotka, NE Siberia): preliminary results. $J$. Paleolimnol., 37:17-35, doi:10.1007/s10933-006-9022-9.

Nolan, M., and Brigham-Grette, J., 2007. Basic hydrology, limnology, and meteorology of modern Lake El'gygytgyn, Siberia. $J$. Paleolimnol., 37:17-35, doi:10.1007/s10933-006-9020-y. 
Nolan, M., Liston, G., Prokein, P., Brigham-Grette, J., Sharpton, V., and Huntzinger, R., 2003. Analysis of lake ice dynamics and morphology on Lake El'gygytgyn, Siberia, using SAR and Landsat. J. Geophys. Res., 108(D2):8062, doi:10.1029/ 2001JD000934.

Nowaczyk, N.R., Melles, M. and Minyuk, P., 2007. A revised age model for core PG1351 from Lake El'gygytgyn, Chukotka, based on magnetic susceptibility variations correlated to northern hemisphere insolation variations. J. Paleolimnol., 37:65-76, doi:10.1007/s10933-006-9023-8.

Ogg, J.G., and Smith, A.G., 2004. The geomagnetic polarity scale. In Gradstein, F.M., Ogg, J.G., and Smith A.G. (Eds.), A Geologic Time Scale 2004. Cambridge (Cambridge University Press), 63-86.

Schwamborn, G., Fedorov, G., Schirrmeister, L., Meyer, H., and Hubberten, H.-W., 2008a. Periglacial sediment variations controlled by Late Quaternary climate and lake level change at Elgygytgyn Crater, Arctic Siberia. Boreas, 37:55-65. doi:10.1111/j.1502-3885.2007.00011.x.

Schwamborn, G., Förster, A., Diekmann, B., Schirrmeister, L., and Fedorov, G., 2008b. Mid to Late Quaternary cryogenic weathering conditions in Chukotka, northeastern Russia: inference from mineralogical and microtextural properties of the Elgygytgyn Crater Lake sediment record.In Kane, D.L., and Hinkel, D.M. (Eds.), Ninth International Conference on Permafrost, Fairbanks (Institute of Northern Engineering, University of Alaska), 1601-1606.

Schwamborn, G., Meyer, H., Fedorov, G., Schirrmeister, L., and Hubberten, H.-W., 2006. Ground ice and slope sediments archiving late Quaternary paleoenvironment and paleoclimate signals at the margins of El'gygytgyn Impact Crater, NE Siberia. Quaternary Res., 66:259-272, doi:10.1016/j. yqres.2006.06.007.

Shilo, N.A., Lozhkin, A.V., Anderson, P.M., Vazhenina, L.N., Stetsenko, T.V., Glushkova, O.Y., and Matrosova, T.V., 2008. First data on the expansion of Larix gmelinii (Rupr.) into arctic regions of Beringia during the early Holocene. Dokl. Akad. Nauk+, 423:680-682.

Yershov, E.D., 1998. General Geocryology. (Studies in Polar Research). Cambridge (Cambridge University Press), 580 pp, doi:10.1017/CBO9780511564505.

\section{Authors}

Martin Melles, Institute of Geology and Mineralogy, University of Cologne, Zuelpicher Str. 49a, D-50674 Cologne, Germany, e-mail: mmelles@uni-koeln.de.

Julie Brigham-Grette, Department of Geosciences, University of Massachusetts, 611 North Pleasant Street, Amherst, MA 01003, U.S.A.

Pavel Minyuk, North-East Interdisciplinary Scientific Research Institute, FEB RAS, 16 Portovaya St., 685000, Magadan, Russia.

Christian Koeberl, Department of Lithospheric Research, University of Vienna, Althanstrasse 14, A-1090 Vienna, Austria (and: Natural History Museum, A-1010 Vienna, Austria).
Andrei Andreev, Institute of Geology and Mineralogy, University of Cologne, Zuelpicher Str. 49a, D-50674 Cologne, Germany.

Timothy Cook, Department of Geosciences, University of Massachusetts, 611 North Pleasant Street, Amherst, MA 01003, U.S.A.

Grigory Fedorov, Arctic and Antarctic Research Institute, Bering Street, 199397 St. Petersburg, Russia.

Catalina Gebhardt, Alfred Wegener Institute for Polar and Marine Research, Am Alten Hafen 26, D-27568 Bremerhaven, Germany.

Eeva Haltia-Hovi, GFZ German Research Centre for Geosciences, Potsdam, Telegrafenberg C321, D-14473 Potsdam, Germany.

Maaret Kukkonen, Institute of Geology and Mineralogy, University of Cologne, Zuelpicher Str. 49a, D-50674 Cologne, Germany.

Norbert Nowaczyk, GFZ German Research Centre for Geosciences, Potsdam, Telegrafenberg C321, D-14473 Potsdam, Germany.

Georg Schwamborn, Alfred Wegener Institute for Polar and Marine Research, Telegrafenberg A43, D-14473 Potsdam, Germany.

Volker Wennrich, Institute of Geology and Mineralogy, University of Cologne, Zuelpicher Str. 49a, D-50674 Cologne, Germany.

and the El'gygytgyn Scientific Party

\section{Related Web Links}

http://elgygytgyn.icdp-online.org http://www.elgygytgyn.uni-koeln.de http://www.geo.umass.edu/lake_e/index.html http://www.dfg-science-tv.de/en/projects/polar-archive http://www.polartrec.com/geologic-climate-researchin-siberia

\section{Figure Credits}

Fig. 1: satellite images from NASA WorldWind Fig. 3A: photo by Tim Martin, Greensboro Day School Fig. 3B: photo by Jens Karls, University of Cologne 